University of Nebraska - Lincoln

DigitalCommons@University of Nebraska - Lincoln

\title{
Foraging Preferences of Canada Geese Among Turfgrasses: Implications for Reducing Human-Goose Conflicts
}

\author{
Brian E. Washburn \\ United States Department of Agriculture, brian.e.washburn@aphis.usda.gov \\ Thomas W. Seamans \\ USDA/APHIS/WS National Wildlife Research Center, thomas.w.seamans@aphis.usda.gov
}

Follow this and additional works at: https://digitalcommons.unl.edu/icwdm_usdanwrc

Washburn, Brian E. and Seamans, Thomas W., "Foraging Preferences of Canada Geese Among

Turfgrasses: Implications for Reducing Human-Goose Conflicts" (2012). USDA National Wildlife Research Center - Staff Publications. 1209.

https://digitalcommons.unl.edu/icwdm_usdanwrc/1209

This Article is brought to you for free and open access by the U.S. Department of Agriculture: Animal and Plant Health Inspection Service at DigitalCommons@University of Nebraska - Lincoln. It has been accepted for inclusion in USDA National Wildlife Research Center - Staff Publications by an authorized administrator of DigitalCommons@University of Nebraska - Lincoln. 


\title{
Foraging Preferences of Canada Geese Among Turfgrasses: Implications for Reducing Human-Goose Conflicts
}

\author{
BRIAN E. WASHBURN, ${ }^{\mathbf{1}}$ United States Department of Agriculture, Wildlife Services, National Wildlife Research Center, Obio Field Station, \\ 6100 Columbus Avenue, Sandusky, OH 44870, USA \\ THOMAS W. SEAMANS, United States Department of Agriculture, Wildlife Services, National Wildlife Research Center, Ohio Field Station, \\ 6100 Columbus Avenue, Sandusky, OH 44870, USA
}

\begin{abstract}
Canada geese (Branta canadensis) can cause serious damage to turfgrass areas and create human health and safety concerns (e.g., collisions with aircraft, disease transmission). We conducted a study during 2005-2007 to determine if Canada geese exhibit a feeding preference among various commercially available turfgrasses. Behavioral responses of captive geese to 9 turfgrasses, bare ground, and litter were observed over 6 4-week trials during July-September following the installation of selected turfgrasses into experimental arenas. Captive geese preferred to forage on Kentucky bluegrass, creeping bentgrass, and fine fescue sods compared to centipedegrass, St. Augustinegrass, and zoysiagrass. Forage qualities and macronutrient levels varied among the turfgrasses and might explain the foraging preferences geese exhibited during this study. Canada goose feeding rate was positively correlated with crude protein, nitrogen content, and calcium, but negatively correlated with acid detergent fiber content, within various turfgrasses. Our findings suggest careful selection of turfgrasses could be an effective method for reducing Canada goose conflicts in urban and suburban areas. (c) 2011 The Wildlife Society.
\end{abstract}

KEY WORDS Branta, feeding, geese, landscape management, nutrition, turfgrasses, urban.

Human-wildlife conflicts occur throughout the world and involve a wide variety of wildlife species and a diversity of problems, including damage to agricultural crop and forest resources, impacts to livestock production, issues related to invasive and exotic species, and wildlife-human disease transmission (Bruggers et al. 2002, Conover 2002, Messmer 2009). Conflicts between humans and wildlife frequently occur in suburban and urban areas, where high densities of humans and wildlife species adapted to living in close proximity to humans co-exist (Adams et al. 2005).

Resident (i.e., non-migratory) Canada geese (Branta canadensis) can be a significant problem within urban and suburban environments. In addition to causing direct damage to vegetation (via trampling and removal), geese grazing on turfgrasses and plants in manicured industrial lawns, parks and recreational areas, on sports fields, on golf courses, and around private homes can adversely affect humans and their use of such areas by littering these areas with feces (Conover and Chasko 1985, Conover 1991). Urban geese directly affect human health and safety by posing a risk to safe aircraft operations (Dolbeer et al. 2000, Dolbeer 2009), contaminating water resources (Conover and Chasko 1985, Manny et al. 1994), behaving aggressively during the nesting season (Smith et al. 1999), and potentially transmitting diseases

Received: 29 November 2010; Accepted: 7 August 2011;

Published: 7 December 2011

${ }^{1}$ E-mail: brian.e.washburn@aphis.usda.gov to humans (Feare et al. 1999, Kullas et al. 2002, Olsen et al. 2006).

Integrated wildlife damage management programs that use a variety of tools and techniques are most effective for reducing human-wildlife conflicts (Fall and Jackson 2002). Management efforts to address resident Canada goose conflicts often involve the use of hazing and scare devices (Smith et al. 1999, York et al. 2000, Holevinksi et al. 2007), habitat modification (Cooper 1998), translocation of individuals (Cooper and Keefe 1997), or lethal removal of geese (Cooper and Keefe 1997, Smith et al. 1999). One component of a management program to reduce human-goose conflicts could be to reduce the attractiveness of turfgrass areas to Canada geese by installing plant species and cultivars (cv.) that are not favored by foraging geese. However, this aspect must be balanced with the aesthetic and recreational values of turfgrass areas for humans (Ulrich 1986, Casler 2006) and the availability, ease of establishment, and maintenance ability of selected turfgrass species and cultivars (Casler and Duncan 2003, Casler 2006).

Knowledge of Canada goose foraging behavior and feeding preferences, especially related to commercially available turfgrasses that are commonly used in urban and suburban situations, could be useful in alleviating human-goose conflicts (Cooper 1998, Conover 1991, Washburn et al. 2007). The objectives of our study were to: 1 ) determine if Canada geese exhibit a foraging preference when given a choice among various commercially available turfgrass types used 
in the United States, 2) quantify forage qualities and nutritional content of these turfgrasses, and 3) identify turfgrass characteristics that might influence foraging preferences by Canada geese.

\section{STUDY AREA}

We conducted this study from June through October 20052007 at the National Aeronautics and Space Administration's Plum Brook Station, Erie County, Ohio ( $41^{\circ} 37^{\prime}$ N, $82^{\circ} 66^{\prime}$ $\mathrm{W})$. Existing goose housing facilities (associated with a fenced 2-ha pond) adjacent to grasslands allowed for experiments on behavioral response of captive birds to different vegetation types without the disturbances characteristic of urban feeding sites (e.g., golf courses).

\section{METHODS}

\section{Study Animals}

We captured wild adult Canada geese of undetermined sex in northern Ohio during the molt period (i.e., June) of 20052007 and transported them to our goose holding facilities where they were provided whole-kernel corn, poultry pellets, grass, and water ad libitum. We trimmed the primary feathers from the right wing of each bird prior to releasing them into the holding facility so that the birds would remain flightless during experiments.

Prior to each experiment, we randomly selected 24 experimentally naive geese and herded them into a 0.4 -ha holding pen that was adjacent to the main holding facility. Wholekernel corn, poultry pellets, shade, grass, and a $20-\mathrm{m}^{2}$ area of the pond were available to geese in the holding pen. Each goose was randomly assigned to 1 of 6 arenas (i.e., 4 geese per arena). We placed an arena-specific color-coded neck band on each goose to ensure the same geese were placed into the same arena throughout an experiment.

\section{Experimental Design}

Each year of the study, we established 5 experimental and 1 control arenas $(12.2 \mathrm{~m} \times 15.2 \mathrm{~m})$. Each arena was divided into $46.1-\mathrm{m} \times 7.6-\mathrm{m}$ plots. We assigned 1 of 4 turfgrasses to each plot within an arena prior to arena construction. We obtained and installed turfgrass sods into the appropriate plot within each arena during June of each year. During 2005 (experiments 1 and 2), the 4 turfgrasses studied included Kentucky bluegrass (Poa pratensis L.; equal mixture of Nudestiny, Award, Rugby II, and Absolute cv.), tall fescue (Schedonorus phoenix (Scop.) Holub) [an equal mixture of an endophyte-free cv. (Arid III) and a high-endophyte cv. (Pixie)], common bermudagrass (Cynodon dactylon L.) cv. Quickstand, and zoysiagrass (Zoysia japonica Steudel) cv. Zenith. During 2006 (experiments 3 and 4), only 3 turfgrass sods [creeping bentgrass (Agrostis stolonifera L.) cv. Penncross, buffalograss (Buchloe dactyloides (Nutt.) Engelm) cv. Legacy, and zoysiagrass cv. Zenith] could be delivered in time for establishment. The fourth plot within each of the 6 arenas was treated as bare ground (i.e., no sod and vegetation killed with glyphosate [Round-up PRO ${ }^{\mathrm{TM}}$, Monstanto Inc., St. Louis, MO]). Following the end of experiment 3, we killed all 5 creeping bentgrass plots using glyphosate on 21 August 2006 because of significant mortality and declines in the quality of the bentgrass turf. Thus, litter (i.e., dead grass) replaced creeping bentgrass as a treatment during experiment 4. During 2007 (experiments 5 and 6), the 4 turfgrasses included fine fescue (mixture comprised of $40 \%$ hard fescue [Festuca trachyphylla (Hackel) Krajina] cv. Nordic, $40 \%$ creeping red fescue [F. rubra ssp. rubra Gaudin] Audubon, and $20 \%$ chewings fescue [F. rubra ssp. commutate (Thuill.) Nyman] cv. Jamestown IV), centipedegrass (Eremochloa ophiuroides (Munro) Hack.) cv. Common, St. Augustinegrass (Stenotaphrum secundatum (Walt.) Kuntze) cv. Palmetto, and zoysiagrass cv. Zenith. Kentucky bluegrass sod was placed in all 4 plots within the control arena in 2005 (experiments 1 and 2), zoysiagrass sod was placed in 3 of the 4 plots within the control arena in 2006 (experiments 3 and 4 ), and zoysiagrass sod was placed in all 4 plots within the control arena in 2007 (experiments 5 and 6).

Following installation and establishment of the turfgrass sod, we erected a $1.5-\mathrm{m}$ tall black plastic fence around the 6 arenas to keep the geese within their respective arenas. We mowed all plots within the arenas to a height of $15-20 \mathrm{~cm}$ prior to the start of the first experiment each year so that all turfgrasses were initially of similar height.

\section{Goose Behavioral Observations}

Each day of an experiment, we placed 20.5 -m diameter pans of water centrally within each arena. We herded 4 geese into each arena daily by 0830 hours and allowed them to graze on the turfgrasses until 1200 hours, when we returned them to their holding pen. Three observers stationed on 4.9-m tall towers $20 \mathrm{~m}$ from the arenas monitored goose activity. We observed geese for 21 -hour periods ( 0.5 and $2.5 \mathrm{hr}$ after we herded geese into arenas) 3 days per week for 4 weeks. Each observer watched 2 arenas, alternating between arenas every minute. At the start of each minute, observers recorded the initial number of geese in each turfgrass plot, then for the following 0.5 minute counted the number of bill contacts (total for all 4 geese) with each turfgrass plot in the arena (Washburn et al. 2007). We conducted behavioral observations of the geese for 12 days during 27 July-19 August 2005 (experiment 1), 24 July-18 August 2006 (experiment 3), and 6 July-1 August 2007 (experiment 5).

Following the end of the first experiment each year, the turfgrasses were not grazed by geese for at least 10 days. We mowed all turfgrass plots to a height of $15-20 \mathrm{~cm}$ prior to the start of the second experiment. We selected a new set of 24 experimentally naive geese, placed them into the holding pen, and fitted them with color-coded neck bands. We conducted behavioral observations of geese during the second 4-week experiment each year for 12 days during 29 August-22 September 2005 (experiment 2), 11 September6 October 2006 (experiment 4), and 10 August-5 September 2007 (experiment 6).

\section{Turfgrass Forage Quality}

We collected fresh samples of the 9 turfgrasses between experiments. We collected 6 replicate samples of each turfgrass from randomly selected arenas by cutting the grass 
swards with electric clippers. We removed dead plant material by hand to ensure samples contained only living plant material. We immediately placed 3 samples of each turfgrass into plastic bags and froze the samples at $-20^{\circ} \mathrm{C}$ within 15 minutes of collection. We placed the remaining 3 samples of each turfgrass in a drying oven within 30 minutes of collection and dried them for 48 hours at $50^{\circ} \mathrm{C}$. We stored dried turfgrass samples individually in paper bags.

We transported frozen turfgrass samples to the Holmes Laboratory, Inc. (Millersburg, OH) for forage and feed analyses. They used standard laboratory methods (Association of Official Analytical Chemists 2007) to determine forage qualities (moisture content, crude fat, crude protein, water-soluble carbohydrates [WSC], acid detergent fiber [ADF], neutral detergent fiber [NDF], lignin, and ash) from each of the 9 turfgrasses. Acid detergent fiber (i.e., cellulose + lignin) has been shown to be a reliable estimator of digestibility of foods in Anatidae (Prop and Deerenberg 1991, Durant et al. 2003). Neutral detergent fiber (i.e., $\mathrm{ADF}+$ hemicelluose) is inversely related to forage intake, thus as NDF increases total intake decreases (Pond et al. 1995).

We sent dried turfgrass samples to the Pennsylvania State University Agricultural Analytical Services Laboratory (University Park, PA) for nutrient and silica content analyses. They used standard laboratory methods for plant tissue analysis (Miller 1998) to determine macronutrient levels (nitrogen, phosphorus, potassium, calcium, magnesium, and sodium) and total silicon in each of the 9 turfgrasses. In grasses, silica uptake is a plant defense against herbivory (Vicari and Bazely 1993) and thus might influence foraging rates by geese.

\section{Statistical Analyses}

We analyzed Canada goose behavioral and feeding rate data from each of the 6 foraging experiments independently. Goose behavioral and foraging data collected during successive observations are likely not independent. Therefore, we computed a daily average of the number of geese per plot and bill contacts per minute for all 4 geese combined (hereafter $\mathrm{BCPM}$ ) for each turfgrass type (i.e., plot) within each arena. We compared the average number of geese observed and the BCPM in each turfgrass type using repeated measures analysis of variance with turfgrass type as a fixed effect, the 5 arenas as replications, and the 12 days as repeated measures (Crowder and Hand 1990). When the main effect (turfgrass type) was found to be significant, we conducted means comparisons using Fisher's protected Least Significant Difference (LSD) tests (Zar 1996). We considered differences significant at $P \leq 0.05$ and conducted all statistical analyses using SAS 9.1 (SAS Institute, Inc., Cary, NC). Additionally, we used linear regression analysis (Zar 1996) to determine if trends in goose foraging rate occurred within individual turfgrass types during each experiment.

We compared forage quality characteristics (moisture, crude fat, crude protein, WSC, ADF, NDF, lignin, and ash), macronutrient levels (nitrogen, phosphorus, potassium, calcium, magnesium, and sodium), and total silica content among the 9 turfgrasses using Kruskal-Wallis tests and considered differences significant at $P \leq 0.05$ (Zar 1996).

We identified potential relationships between observed goose foraging and the forage quality and nutritional characteristics of the turfgrasses. We calculated Pearson's correlation coefficient for goose foraging rate (BCPM; averaged across experiments) with each forage quality characteristic (moisture, crude fat, crude protein, WSC, ADF, NDF, lignin, and ash), macronutrient level (nitrogen, phosphorus, potassium, calcium, magnesium, and sodium), and total silica content for each of the 9 turfgrasses and considered correlations to be significant at $P \leq 0.05$ (Zar 1996).

\section{RESULTS}

\section{Goose Behavioral and Foraging Observations}

During experiment 1 , the numbers of geese observed did not differ $\left(F_{3,16}=1.86, P=0.18\right)$ and the BCPM was not statistically different $\left(F_{3,16}=2.87, P=0.07\right)$ among the 4 turfgrasses (Table 1). However, the BCPM by geese in bluegrass, tall fescue, and bermudagrass plots was more than 22 times greater than BCPM by geese in zoysiagrass plots (Fig. 1A). We believe this difference is biologically significant and represents an important difference in feeding rate. Canada geese foraged in the Kentucky bluegrass control

Table 1. Mean number of Canada geese per plot and mean number of bill contacts per minute (for 4 geese combined) during 6 experiments with commercially available turfgrasses. Data are presented as mean $\pm 1 \mathrm{SE}$.

\begin{tabular}{llc}
\hline Turfgrass & $\begin{array}{c}\text { No. of geese } \\
\text { per plot }^{\mathbf{a}}\end{array}$ & $\begin{array}{c}\text { Bill contacts } \\
\text { per minute }^{\mathbf{a}}\end{array}$ \\
\hline Experiment 1 & & \\
$\quad$ Kentucky bluegrass & $0.8 \pm 0.1 \mathrm{~A}$ & $22.3 \pm 6.6 \mathrm{~A}$ \\
Tall fescue & $1.2 \pm 0.5 \mathrm{~A}$ & $22.4 \pm 10.2 \mathrm{~A}$ \\
Common bermudagrass & $1.2 \pm 0.3 \mathrm{~A}$ & $28.4 \pm 7.5 \mathrm{~A}$ \\
Zoysiagrass & $0.4 \pm 0.1 \mathrm{~A}$ & $0.8 \pm 0.2 \mathrm{~A}$ \\
Experiment 2 & & \\
Kentucky bluegrass & $1.7 \pm 0.2 \mathrm{~A}$ & $81.7 \pm 11.2 \mathrm{~A}$ \\
Tall fescue & $0.6 \pm 0.2 \mathrm{~B}$ & $5.3 \pm 1.4 \mathrm{C}$ \\
Common bermudagrass & $1.0 \pm 0.2 \mathrm{AB}$ & $19.3 \pm 3.4 \mathrm{~B}$ \\
Zoysiagrass & $0.4 \pm 0.2 \mathrm{~B}$ & $1.9 \pm 0.6 \mathrm{C}$ \\
Experiment 3 & & \\
Creeping bentgrass & $1.2 \pm 0.2 \mathrm{~A}$ & $41.9 \pm 5.0 \mathrm{~A}$ \\
Buffalograss & $0.7 \pm 0.2 \mathrm{~A}$ & $18.8 \pm 5.4 \mathrm{AB}$ \\
Zoysiagrass & $0.6 \pm 0.2 \mathrm{~A}$ & $6.0 \pm 2.3 \mathrm{~B}$ \\
Bare ground (no grass) & $1.1 \pm 0.3 \mathrm{~A}$ & $1.3 \pm 0.4 \mathrm{~B}$ \\
Experiment 4 & & \\
Litter (dead grass) & $0.7 \pm 0.3 \mathrm{~A}$ & $0.5 \pm 0.2 \mathrm{~A}$ \\
Buffalograss & $1.8 \pm 0.3 \mathrm{~B}$ & $36.5 \pm 3.6 \mathrm{~B}$ \\
Zoysiagrass & $0.6 \pm 0.3 \mathrm{~A}$ & $6.2 \pm 2.5 \mathrm{~A}$ \\
Bare ground (no grass) & $0.7 \pm 0.1 \mathrm{~A}$ & $1.1 \pm 0.3 \mathrm{~A}$ \\
Experiment 5 & & \\
Fine fescue & $2.0 \pm 0.4 \mathrm{~A}$ & $19.0 \pm 3.4 \mathrm{~A}$ \\
Centipedegrass & $0.8 \pm 0.2 \mathrm{~B}$ & $4.1 \pm 1.0 \mathrm{~B}$ \\
St. Augustinegrass & $0.5 \pm 0.2 \mathrm{~B}$ & $5.6 \pm 1.6 \mathrm{~B}$ \\
Zoysiagrass & $0.4 \pm 0.1 \mathrm{~B}$ & $3.6 \pm 0.9 \mathrm{~B}$ \\
Experiment 6 & & \\
Fine fescue & $1.8 \pm 0.2 \mathrm{~A}$ & $32.0 \pm 5.3 \mathrm{~A}$ \\
Centipedegrass & $0.7 \pm 0.3 \mathrm{~B}$ & $6.3 \pm 2.4 \mathrm{~B}$ \\
St. Augustinegrass & $0.5 \pm 0.2 \mathrm{~B}$ & $2.7 \pm 0.9 \mathrm{~B}$ \\
Zoysiagrass & $0.4 \pm 0.1 \mathrm{~B}$ & $3.0 \pm 1.1 \mathrm{~B}$ \\
\hline
\end{tabular}

${ }^{\text {a }}$ Within each experiment, means within the same column with the same letter are not different $(P>0.05)$. 


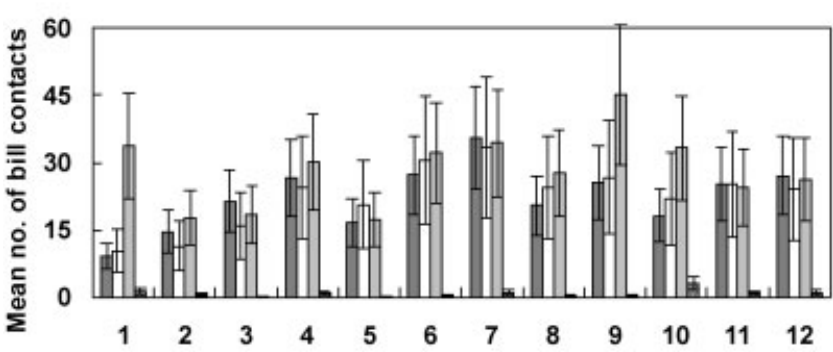

\section{B $\square$ Bluegrass $\square$ Tall Fescue $\square$ Bermudagrass $\square$ Zoysiagrass}

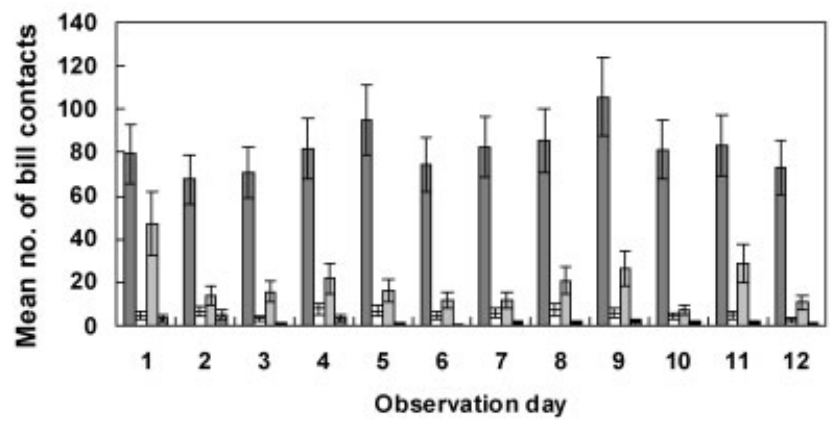

Figure 1. Mean number of bill contacts per minute by captive Canada geese in 5 arenas of 4 turfgrass plots during (A) experiment 1, 27 July-19 August 2005 and (B) experiment 2, 29 August-22 September 2005.

arena plots (10.6 BCPM) at rates consistent with foraging in bluegrass sod within the other 5 arenas. Overall, captive Canada geese spent similar amounts of time in all 4 types of turfgrass but foraged almost exclusively on the Kentucky bluegrass, tall fescue, and common bermudagrass sod (Fig. 1A).

During experiment 2, the numbers of geese observed in Kentucky bluegrass were greater $\left(F_{3,16}=10.61, P \leq 0.001\right)$ than in tall fescue and zoysiagrass plots, whereas the numbers of geese in common bermudagrass plots were similar to the other 3 turfgrasses (Table 1). The BCPM by geese in bluegrass was $4-43$ times greater $\left(F_{3,16}=39.79, P \leq 0.001\right)$ than in tall fescue, bermudagrass, and zoysiagrass plots (Table 1). Canada geese foraged in the Kentucky bluegrass control arena plots (18.0 BCPM) at a rate less than in the other 5 arenas. Overall, captive Canada geese preferred to loaf, preen, rest, and forage in Kentucky bluegrass plots compared to tall fescue and zoysiagrass plots (Fig. 1B).

During experiment 3 , the numbers of geese observed was similar $\left(F_{3,16}=2.38, P=0.11\right)$ among the 3 turfgrass and bare ground plots (Table 1). The number of bill contacts by geese in creeping bentgrass plots was 7-32 times greater $\left(F_{3,16}=21.79, P<0.001\right)$ than the number of bill contacts by geese in zoysiagrass or bare ground plots; the number of bill contacts by geese in buffalograss was intermediate (Table 1). Canada goose foraging on creeping bentgrass decreased (linear regression: $y=-3.6211 x+65.402$, $\left.R^{2}=0.36, F_{1,11}=5.67, P=0.04\right)$, while foraging on buffalograss increased (linear regression: $y=3.3213 x-2.838$, $\left.R^{2}=0.83, F_{1,11}=47.27, P<0.001\right)$ from the beginning to the end of experiment 3 (Fig. 2A). Canada geese in the
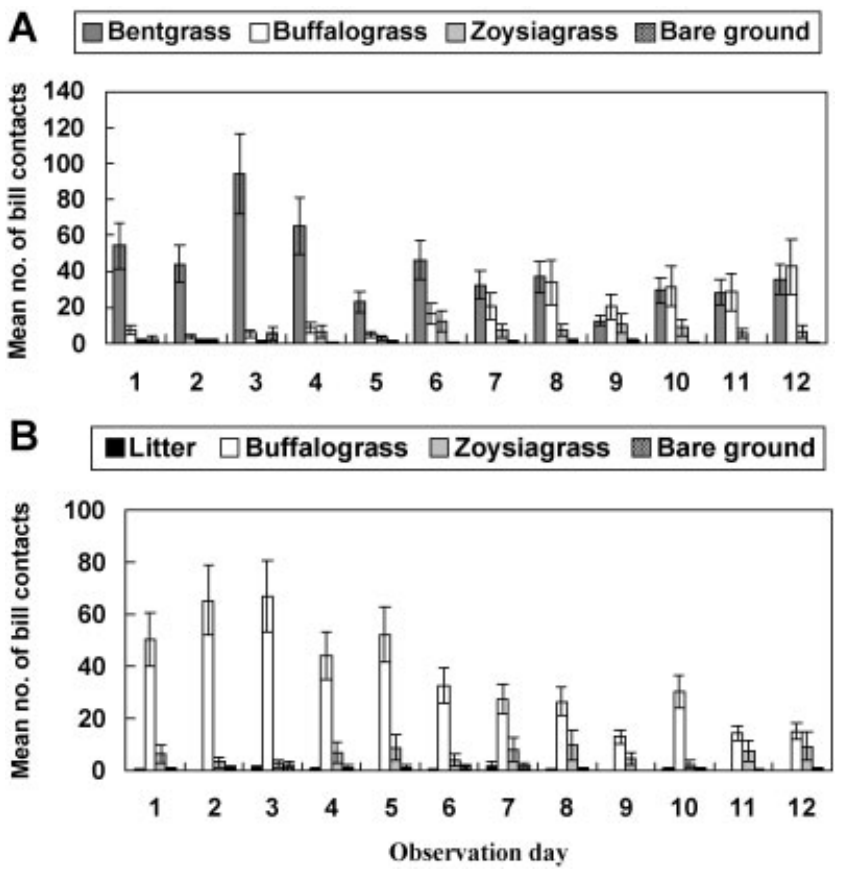

Figure 2. Mean number of bill contacts per minute by captive Canada geese in 5 arenas of 4 turfgrass plots during (A) experiment 3, 24 July-18 August 2006 and (B) experiment 4, 11 September-6 October 2006.

control arena plots foraged in the zoysiagrass (12.3 BCPM) and bare ground (2.7 BCPM) plots similarly to the other 5 arenas. Overall, geese spent similar amounts of time in all 3 turfgrass and bare ground plots but foraged almost exclusively in the creeping bentgrass and buffalograss plots (Fig. 2A).

During experiment 4 , more $\left(F_{3,16}=4.46, P=0.02\right)$ geese were observed in buffalograss than in zoysiagrass, bare ground, and litter plots (Table 1). The number of bill contacts by geese in buffalograss was 6-73 times greater $\left(F_{3,16}=60.68, P<0.001\right)$ than the number of bill contacts by geese in zoysiagrass, bare ground, and litter plots. Canada goose foraging on buffalograss decreased (linear regression: $y=-3.6211 x+65.402 ; \quad R^{2}=0.79, \quad F_{1,11}=37.08$, $P<0.001)$ from the beginning to the end of experiment 3 (Fig. 2B). Canada geese foraged in the zoysiagrass (10.2 $\mathrm{BCPM})$ and bare ground (1.0 BCPM) control plots at rates consistent with foraging within the other 5 arenas. Overall, captive Canada geese preferred to loaf, preen, rest, and forage in buffalograss plots compared to zoysiagrass, bare ground, and litter plots (Fig. 2B).

During experiments 5 and 6 , the numbers of geese observed in fine fescue were greater (experiment 5: $F_{3,16}=8.29$, $P=0.002$; experiment 6: $\left.F_{3,16}=9.59, P \leq 0.001\right)$ than in centipedegrass, St. Augustinegrass, and zoysiagrass plots (Table 1). The number of bill contacts by geese in fine fescue was 3-5 times greater $\left(F_{3,16}=13.81, P \leq 0.001\right)$ and $5-12$ times greater $\left(F_{3,16}=22.58, P \leq 0.001\right)$ than the number of bill contacts by geese in centipedegrass, St. Augustinegrass, and zoysiagrass plots during experiments 5 and 6 , respectively. Canada geese in the control plot arena foraged in the 


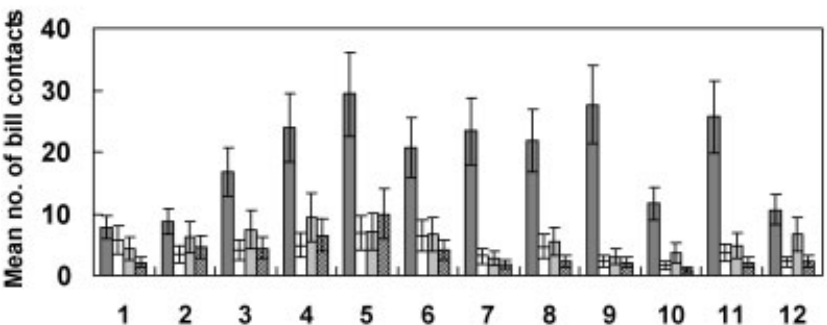

\section{B $\square$ Fine Fescue $\square$ Centipede $\square$ St. Augustine $\square$ Zoysiagrass}

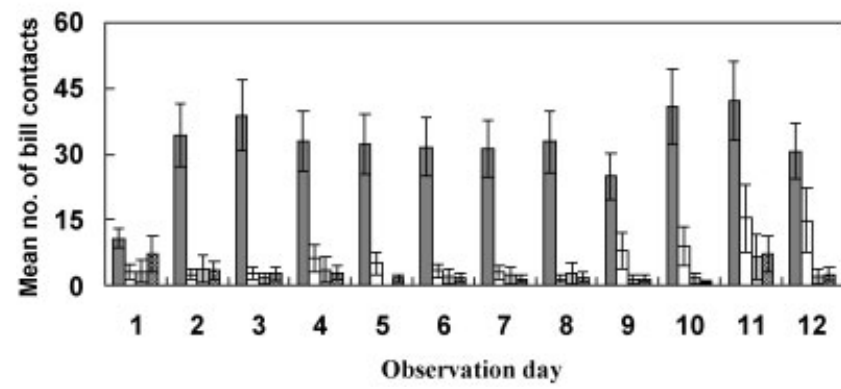

Figure 3. Mean number of bill contacts per minute by captive Canada geese in 5 arenas of 4 turfgrass plots during (A) experiment 5, 6 July-1 August 2007 and (B) experiment 6, 10 August-5 September 2007.

zoysiagrass control plots (experiment 5: 7.3 BCPM; experiment 6: 11.5 BCPM) at rates consistent with foraging in the zoysiagrass plots within the other 5 arenas. Overall, captive Canada geese preferred to loaf, preen, rest, and forage in fine fescue plots compared to centipedegrass, St. Augustinegrass, and zoysiagrass (Fig. 3A,B).

\section{Turfgrass Forage Quality}

Forage quality characteristics (Table 2) varied among the 9 turfgrasses (all $H_{8}>18.2, P<0.03$ ). Buffalograss had the lowest moisture content, whereas creeping bentgrass had the highest (Table 2). Fine fescue and centipedegrass had greater crude fat than tall fescue (Table 2). Kentucky bluegrass and creeping bentgrass had greater levels of crude protein than common bermudagrass and zoysiagrass (Table 2). Acid detergent fiber was lowest in Kentucky bluegrass and creeping bentgrass and highest in buffalograss and zoysiagrass (Table 2). Tall fescue had less NDF and more WSC than zoysiagrass (Table 2).

Macronutrient levels (Table 3) varied among the 9 turfgrasses (all $H_{8}>24.0, P<0.003$ ). Kentucky bluegrass and creeping bentgrass had greater nitrogen content than common bermudagrass and zoysiagrass (Table 3 ). Calcium levels were highest in common bermudagrass and lowest in St. Augustinegrass and zoysiagrass (Table 3 ). St. Augustinegrass had sodium levels that were 5-72 times greater than the other 8 turfgrasses studied (Table 3). Buffalograss had greater total silica content than fine fescue and creeping bentgrass (Table 3).

\section{Relationships Between Turfgrass Forage Quality and Goose Foraging}

Goose foraging rate (i.e., BCPM) and forage quality characteristics of turfgrasses were positively correlated for crude protein $(r=0.70, P=0.03, n=9$ grasses $)$ and negatively correlated for $\mathrm{ADF}(r=-0.71, P=0.03, n=9)$, whereas correlations between goose foraging rate and turfgrass forage qualities were absent (all $P>0.05$ ) for moisture, ash, crude fiber, WSC, NDF, and lignin. Goose foraging rate and macronutrient levels in the turfgrasses were positively correlated for nitrogen $(r=0.73, P=0.03, n=9)$ and calcium $(r=0.75, P=0.02, n=9)$, whereas correlations between goose foraging rate and turfgrass forage qualities were absent (all $P>0.05$ ) for the other macronutrients measured (phosphorus, potassium, magnesium, sodium) and total silica content.

\section{DISCUSSION}

Our findings clearly demonstrate that Canada geese were making choices and exhibiting preferences when foraging among the turfgrass plots. The forage selection patterns of Canada geese for Kentucky bluegrass in this study are consistent with the findings of other research (Conover 1991, Pochop et al. 1999). Conover (1991) found that Canada geese readily foraged on colonial bentgrass (Agrostis castellana Boiss. \& Reuter cv. Highland), a cool-season grass very

Table 2. Forage qualities of Kentucky bluegrass (KYB), common bermudagrass (BERM), tall fescue (TTF), zoysiagrass (ZOY), creeping bentgrass (BENT), buffalograss (BUFF), fine fescue (FF), centipedegrass (CENT), and St. Augustinegrass (ST. AUG). Data are presented as mean \pm 1 SE.

\begin{tabular}{|c|c|c|c|c|c|c|c|c|}
\hline Turfgrass & $\begin{array}{c}\text { Moisture } \\
\text { (\%) }\end{array}$ & $\begin{array}{l}\text { Ash } \\
\text { (\%) }\end{array}$ & $\begin{array}{l}\text { Crude fat } \\
\left.\text { (\%AFDW }{ }^{a}\right)\end{array}$ & $\begin{array}{l}\text { Crude protein } \\
\text { (\%AFDW) }\end{array}$ & $\begin{array}{c}\text { WSC }^{\mathbf{b}} \\
(\% A F D W)\end{array}$ & $\begin{array}{c}\text { ADF }^{\mathrm{c}} \\
(\% A F D W)\end{array}$ & $\begin{array}{c}\text { NDF }^{\mathrm{d}} \\
(\% A F D W)\end{array}$ & $\begin{array}{c}\text { Lignin } \\
\text { (\%AFDW) }\end{array}$ \\
\hline KYB & $69.9 \pm 1.7$ & $8.5 \pm 0.3$ & $2.7 \pm 0.1$ & $22.8 \pm 0.5$ & $20.0 \pm 1.0$ & $24.5 \pm 1.2$ & $55.5 \pm 1.0$ & $0.5 \pm 0.2$ \\
\hline BERM & $57.0 \pm 3.9$ & $6.6 \pm 0.1$ & $1.6 \pm 0.2$ & $11.4 \pm 0.5$ & $8.7 \pm 3.7$ & $31.2 \pm 0.2$ & $76.1 \pm 3.0$ & $3.9 \pm 0.3$ \\
\hline TTF & $72.6 \pm 1.5$ & $11.9 \pm 0.1$ & $1.4 \pm 0.1$ & $15.3 \pm 0.8$ & $24.9 \pm 0.9$ & $29.4 \pm 0.5$ & $52.0 \pm 0.7$ & $0.9 \pm 0.1$ \\
\hline ZOY & $62.8 \pm 2.1$ & $7.7 \pm 0.2$ & $1.6 \pm 0.1$ & $11.8 \pm 0.7$ & $3.3 \pm 1.3$ & $33.3 \pm 0.4$ & $80.9 \pm 1.3$ & $2.1 \pm 0.2$ \\
\hline BENT & $85.2 \pm 1.3$ & $14.6 \pm 1.3$ & $2.6 \pm 0.1$ & $31.2 \pm 0.5$ & $16.3 \pm 2.9$ & $23.2 \pm 0.4$ & $62.2 \pm 9.9$ & $1.2 \pm 0.4$ \\
\hline BUFF & $45.3 \pm 0.9$ & $8.6 \pm 0.1$ & $1.6 \pm 0.1$ & $14.4 \pm 0.5$ & $10.7 \pm 3.0$ & $32.8 \pm 0.4$ & $72.3 \pm 3.0$ & $2.7 \pm 0.1$ \\
\hline $\mathrm{FF}$ & $72.4 \pm 2.1$ & $8.7 \pm 0.1$ & $3.2 \pm 0.1$ & $20.2 \pm 0.3$ & $11.9 \pm 5.9$ & $28.6 \pm 0.5$ & $67.4 \pm 8.1$ & $0.6 \pm 0.1$ \\
\hline CENT & $75.2 \pm 1.0$ & $8.9 \pm 0.2$ & $3.4 \pm 0.4$ & $13.7 \pm 0.8$ & $12.7 \pm 3.6$ & $31.0 \pm 1.2$ & $68.8 \pm 3.1$ & $1.3 \pm 0.3$ \\
\hline ST. AUG & $76.6 \pm 1.5$ & $9.7 \pm 0.2$ & $2.0 \pm 0.1$ & $17.1 \pm 0.6$ & $16.3 \pm 1.0$ & $28.6 \pm 0.3$ & $63.6 \pm 0.2$ & $0.7 \pm 0.1$ \\
\hline
\end{tabular}

a $\% A F D W=$ Percent ash-free dry weight.

${ }^{\mathrm{b}} \mathrm{WSC}=$ water-soluble carbohydrates.

${ }^{\mathrm{c}} \mathrm{ADF}=$ acid detergent fiber.

${ }^{\mathrm{d}} \mathrm{NDF}=$ neutral detergent fiber. 
Table 3. Macronutrient and total silica (expressed on a dry weight-basis) in Kentucky bluegrass (KYB), common bermudagrass (BERM), tall fescue (TTF), zoysiagrass (ZOY), creeping bentgrass (BENT), buffalograss (BUFF), fine fescue (FF), centipedegrass (CENT), and St. Augustinegrass (ST. AUG). Data are presented as mean $\pm 1 \mathrm{SE}$.

\begin{tabular}{lccccccc}
\hline Turfgrass & Nitrogen (\%) & Phosphorus (\%) & Potassium (\%) & Calcium (\%) & Magnesium (\%) & Sodium (\%) & Silicon (mg/kg) \\
\hline KYB & $3.61 \pm 0.07$ & $0.31 \pm 0.02$ & $2.33 \pm 0.06$ & $0.43 \pm 0.03$ & $0.19 \pm 0.02$ & $0.04 \pm 1.20$ & $11,199 \pm 394$ \\
BERM & $1.76 \pm 0.06$ & $0.24 \pm 0.01$ & $1.13 \pm 0.03$ & $0.47 \pm 0.09$ & $0.14 \pm 0.01$ & $0.08 \pm 0.01$ & $12,085 \pm 900$ \\
TTF & $2.05 \pm 0.09$ & $0.42 \pm 0.01$ & $2.52 \pm 0.04$ & $0.22 \pm 0.09$ & $0.35 \pm 0.01$ & $0.01 \pm 0.01$ & $20,388 \pm 529$ \\
ZOY & $1.78 \pm 0.07$ & $0.31 \pm 0.02$ & $1.54 \pm 0.03$ & $0.18 \pm 0.02$ & $0.14 \pm 0.01$ & $0.01 \pm 0.01$ & $14,270 \pm 322$ \\
BENT & $5.29 \pm 0.01$ & $0.61 \pm 0.01$ & $3.28 \pm 0.01$ & $0.67 \pm 0.02$ & $0.24 \pm 0.01$ & $0.04 \pm 0.01$ & $4,826 \pm 97$ \\
BUFF & $2.18 \pm 0.06$ & $0.28 \pm 0.01$ & $0.92 \pm 0.01$ & $0.23 \pm 0.05$ & $0.12 \pm 0.01$ & $0.01 \pm 0.01$ & $22,510 \pm 573$ \\
FF & $3.08 \pm 0.04$ & $0.38 \pm 0.01$ & $2.55 \pm 0.05$ & $0.37 \pm 0.01$ & $0.19 \pm 0.01$ & $0.01 \pm 0.01$ & $8,877 \pm 199$ \\
CENT & $2.06 \pm 0.06$ & $0.34 \pm 0.01$ & $2.24 \pm 0.02$ & $0.28 \pm 0.02$ & $0.25 \pm 0.01$ & $0.01 \pm 0.01$ & $14,032 \pm 360$ \\
ST. AUG & $2.32 \pm 0.02$ & $0.46 \pm 0.01$ & $2.55 \pm 0.02$ & $0.15 \pm 0.03$ & $0.25 \pm 0.01$ & $0.43 \pm 0.04$ & $11,349 \pm 753$ \\
\hline
\end{tabular}

closely related to creeping bentgrass. In addition to foraging, time in each plot might be spent loafing or in other nonfeeding behaviors (Belant et al. 1997). Although geese also spent time in the zoysiagrass plots, they showed little preference for this turfgrass when foraging.

Overall, the rate of Canada goose foraging upon the various turfgrasses was consistent during the experiments, with 2 interesting exceptions. During experiment 3, the creeping bentgrass sod exhibited a visible reduction in turfgrass quality (it appeared to be dying from an unknown disease) which reduced the quantity and likely the forage quality of available bentgrass in the plots. Although Canada goose foraging rates decreased as the experiment progressed, they continued to forage on this sod at a high rate in all 5 arenas. This suggests that the creeping bentgrass provided a favorable forage (compared to other turfgrasses) to the geese. Canada goose foraging on buffalograss increased during experiment 3 and then steadily decreased during experiment 4 . As buffalograss is a warm-season grass, we suspect the responses in feeding rate by geese followed the forage value of buffalograss during its annual cycle.

The nutritional content of most turfgrass species and cv. are unknown, primarily because these grass species or specific turf-type cv. are not used as for forage in animal production agriculture (Ball et al. 1991). Geese, because of their high daily energy requirements and simple gastrointestinal tract with a limited ability to digest fiber (Buchsbaum et al. 1986, Sedinger et al. 1989, Sedinger 1997), need to ingest large quantities of forage with high concentrations of digestible nutrients to meet their nutritional needs (Ydenberg and Prins 1981, Durant et al. 2004). Therefore, grazing Anatidae (including various species of geese) apparently make foraging choices based on the nutritional content and chemical composition of plants (Owen 1975, Gauthier and Bedard 1991, McKay et al. 2001). Geese prefer to forage on plants that are high in water and protein content (Owen 1973, Owen et al. 1977, Sedinger and Raveling 1984, McKay et al. 2001). Digestible crude protein intake is an important component in the foraging decisions of geese (Sedinger 1997, Durant et al. 2004). Protein concentration within forage plants has been shown to influence forage selection in a variety of goose species, including barnacle geese (Branta leucopsis; Prins and Ydenberg 1985), darkbellied brent geese (B. bernicla bernicla; McKay et al. 2001), white-fronted geese (Anser albifrons albifrons; Owen
1976), graylag geese (A. anser; Van Liere et al. 2009), and gosling Canada geese (Sedinger and Raveling 1984). In this study, adult Canada geese foraged most on and therefore seemed to select turfgrasses (i.e., Kentucky bluegrass, creeping bentgrass, and fine fescue) that exceeded $20 \%$ protein (or nitrogen) content.

In addition to protein levels, $\mathrm{ADF}$ might influence forage selection by geese. The turfgrasses fed upon most often by Canada geese in this study (i.e., Kentucky bluegrass and creeping bentgrass) had low levels of ADF whereas turfgrasses that were less fed upon (i.e., centipedegrass and zoysiagrass) contained high levels of ADF. Gauthier and Hughes (1995) found that high fiber content appeared to reduce greater snow goose (Chen caerulescens atlantica) foraging on willow (Salix spp.) leaves. Also, Prop et al. (2005) found that $\mathrm{ADF}$ had a negative effect on the digestibility of organic matter by barnacle geese.

With the exception of calcium, our findings suggest macronutrient (e.g., mineral) content of turfgrasses does not appear to affect foraging choice by geese. Similarly, Mathers and Montgomery (1997) found forage choice in free-ranging pale-bellied brent geese (B. bernicla brota) was related to forage quality (e.g., low fiber content) rather than mineral content of consumed forage plants. Prins and Ydenberg (1985) found protein levels, but not minerals, influenced diet choice in wintering barnacle geese. However, lesser snow geese (C. caerulescens caerulescens) selected plants based on the nutrient content in order to obtain necessary minerals (nitrogen, calcium and phosphorous) to promote growth while on their breeding grounds (Gadallah and Jefferies 1995). Consequently, mineral content of plants might influence goose forage selection during certain periods of the year when energetic demands for those minerals are high (e.g., egg production).

Secondary plant defense compounds, such as alkaloids and tannins, cause geese to limit intake of or avoid feeding on certain plants (Buchsbaum et al. 1984, Conover 1991, Gauthier and Hughes 1995). The tall fescue endophyte (Neotyphodium coenophialum) is a naturally occurring fungus that forms a symbiotic relationship with the grass (Ball et al. 1991). Secondary plant defense compounds (e.g., alkaloids) produced by endophyte-infected tall fescue act as a feeding deterrent (e.g., taste aversion) by causing post-ingestion distress in animals that consume the plant (Aldrich et al. 1993, Schmidt and Osborn 1993, Bacon and Hill 1997). 
Many tall fescue cv. have high levels of tall fescue endophyte infection (Mohr et al. 2002). In this study, we used a turfgrass sod grown from a mix of endophyte-free and high-endophyte tall fescue cv. We suspect that the foraging on tall fescue that occurred (primarily in experiment 1 ) was a result either of the geese selectively grazing the endophytefree tall fescue plants within the plots or geese were ingesting the high-endophyte tall fescue at levels low enough to avoid the negative effects of alkaloid consumption. Washburn et al. (2007) found captive Canada geese avoided foraging on high-endophyte tall fescue turfgrass sod when the percent of tall fescue within the sward exceeded 90\%. Also, Conover and Messmer (1996) reported captive Canada geese preferred to graze on non-infected tall fescue $\mathrm{cv}$. compared to endophyte-infected tall fescue cv., and that geese foraging on endophyte-infected tall fescue suffered negative effects (e.g., lost body mass).

In addition to nutrient levels and plant defense chemicals, physical characteristics of turfgrasses (e.g., leaf tensile strength, hairy leaves) might influence forage selection by Canada geese (Lieff et al. 1970, Williams and Forbes 1980, Conover 1991). Although we did not specifically examine physical characteristics of turfgrasses in our study, we believe future research efforts to further understand the influence of physical and/or nutritional characteristics upon forage selection patterns in Anatidae might consider evaluating physical characteristics of turfgrasses.

We acknowledge our study was conducted in a captive setting and that free-ranging Canada geese might exhibit different foraging preferences among turfgrasses that are available with a given landscape. We recommend field trials be conducted in various parts of the United States (and elsewhere) to determine which turfgrasses and turf-type cv. might be useful in different physiographic regions of North America.

\section{MANAGEMENT IMPLICATIONS}

The findings from our 3-year study of foraging preferences by Canada geese suggest selected commercially available turfgrasses (e.g., zoysiagrass, centipedegrass, and St. Augustinegrass) might be particularly useful in reseeding and vegetation renovation projects within areas where Canada geese are unwanted (e.g., parks, athletic fields, airports, and golf courses). Conversely, creeping bentgrass, Kentucky bluegrass, and fine fescues should be avoided when formulating seed mixtures for reseeding areas where human-goose conflicts might occur. We recommend managers and landscapers use caution when selecting common bermudagrass and buffalograss for reseeding projects, especially when other less preferred turfgrasses are present in the general area.

The avoidance or preference for certain turfgrasses by foraging geese might be due to the nutritional value, the physical characteristics of these turfgrasses, the presence of secondary plant defense compounds, or a combination of factors. Thus, an understanding of how the physical and nutritional characteristics of commercially available turfgrasses influence forage selection by geese could be useful for predicting the attractiveness of those plants to Canada geese and allow for the selection of grasses that might reduce human-goose conflicts in some situations.

Attractiveness to foraging wildlife (e.g., Canada geese) is one aspect of turfgrass selection that must be balanced with the aesthetic and recreational values of turfgrass areas for humans. In addition, managers and landscapers must consider the availability, ease of establishment, and maintenance ability of selected turfgrass species and cultivars when selecting turfgrasses for reseeding and revegetation projects.

\section{ACKNOWLEDGMENTS}

R. Beason, B. Blackwell, L. Kutschbach-Brohl, D. Helon, S. Johnston, L. Tyson, T. DeVault, and others provided field assistance and comments on earlier drafts of the manuscript. We thank the National Aeronautics and Space Administration for providing access to the study site. Funding for this study was provided by the Federal Aviation Administration (FAA). Opinions expressed in this study do not necessarily reflect current FAA policy decisions governing the control of wildlife on or near airports.

\section{LITERATURE CITED}

Adams, C. E., K. J. Lindsey, and S. J. Ash. 2005. Urban wildlife management. CRC Press, Boca Raton, Florida, USA.

Aldrich, C. G., J. A. Paterson, J. L. Tate, and M. S. Kerley. 1993. The effects of endophyte infected tall fescue on diet utilization and thermal regulation in cattle. Journal of Animal Science 71:164-170.

Association of Official Analytical Chemists. 2007. Official methods of analysis. Association of Official Analytical Chemists, Washington, D.C., USA.

Bacon, C. W., and N. S. Hill. 1997. Neotyphodium/grass interactions. Plenum Publishing Corporation, New York, New York, USA.

Ball, D. M., C. S. Hoveland, and G. D. Lacefield. 1991. Southern forages. Williams Printing Company, Atlanta, Georgia, USA.

Belant, J. L., L. A. Tyson, T. W. Seamans, and S. K. Ickes. 1997. Evaluation of lime as an avian feeding repellent. Journal of Wildlife Management 61:917-924.

Bruggers, R. L., R. Owens, and T. Hoffman. 2002. Wildlife damage management research needs: perceptions of scientists, wildlife managers, and stakeholders of the USDA/Wildlife Services program. International Biodeterioration \& Biodegredation 49:213-223.

Buchsbaum, R., I. Valiela, and T. Swain. 1984. The role of phenolic compounds and other plant constituents in feeding by Canada geese in a coastal marsh. Oecologia 63:343-349.

Buchsbaum, R., J. Wilson, and I. Valiela. 1986. Digestibility of plant constituents by Canada geese and Atlantic brant. Ecology 67:386-393.

Casler, M. D. 2006. Perennial grasses for turf, sport, and amenity uses: evolution of form, function, and fitness for human benefit. Journal of Agricultural Science 144:189-203.

Casler, M. D., and R. R. Duncan. 2003. Turfgrass biology, genetics, and breeding. John Wiley and Sons, New York, New York, USA.

Conover, M. R. 1991. Herbivory by Canada geese: diet selection and effect on lawns. Ecological Applications 1:231-236.

Conover, M. R. 2002. Resolving human-wildlife conflicts: the science of wildlife damage management. CRC Press, Boca Raton, Florida, USA.

Conover, M. R., and G. G. Chasko. 1985. Nuisance Canada goose problems in the Eastern United States. Wildlife Society Bulletin 13:228-233.

Conover, M. R., and T. A. Messmer. 1996. Feeding preferences and changes in mass of Canada geese grazing endophyte-infeced tall fescue. Condor 98:859-862.

Cooper, J. A. 1998. The potential for managing urban Canada geese by modifying habitat. Proceedings of the Vertebrate Pest Conference 18:18-25. 
Cooper, J. A., and T. Keefe. 1997. Urban Canada goose management: policies and procedures. Transactions of the North American Wildlife and Natural Resources Conference 62:413-430.

Crowder, M. J., and D. J. Hand. 1990. Analysis of repeated measures. Chapman \& Hall, London, United Kingdom.

Dolbeer, R. A. 2009. Birds and aircraft-fighting for airspace in ever more crowded skies. Human-Wildlife Conflicts 3:165-166.

Dolbeer, R. A., S. E. Wright, and E. C. Cleary. 2000. Ranking the hazard of wildlife species to aviation. Wildlife Society Bulletin 28:372-378.

Durant, D., H. Fritz, S. Blais, and P. Duncan. 2003. The functional response in three species of herbivorous Anatidae: effects of sward height, body mass, and bill size. Journal of Animal Ecology 72:220-231.

Durant, D., H. Fritz, and P. Duncan. 2004. Feeding patch selection by herbivorous Anatidae: the influence of body size, and of plant quantity and quality. Journal of Avian Biology 25:144-152.

Fall, M. W., and W. B. Jackson. 2002. The tools and techniques of wildlife damage management-challenging needs: an introduction. International Biodeterioration \& Biodegredation 49:87-91.

Feare, C. J., M. F. Sanders, R. Blasco, and J. D. Bishop. 1999. Canada geese (Branta canadensis) droppings as a potential source of pathogenic bacteria. Journal of the Royal Society for the Promotion of Health 119:146-155.

Gadallah, F. L., and R. L. Jefferies. 1995. Comparison of the nutrients contents of the principal forage plants utilized by lesser snow geese on summer breeding grounds. Journal of Applied Ecology 32:263-275.

Gauthier, G., and J. Bedard. 1991. Experimental tests of the palatability of forage plants in greater snow geese. Journal of Applied Ecology 28:491500.

Gauthier, G., and R. J. Hughes. 1995. The palatability of Arctic willow for greater snow geese: the role of nutrients and deterring factors. Oecologia 103:390-392.

Holevinksi, R. A., P. D. Curtis, and R. A. Malecki. 2007. Hazing of Canada geese is unlikely to reduce nuisance populations in urban and suburban communities. Human-Wildlife Conflicts 1:257-264.

Kullas, H., M. Coles, J. Rhyan, and L. Clark. 2002. Prevalance of Escherichia coli serogroups and human virulence factors in faeces of urban Canada geese (Branta canadensis). International Journal of Environmental Health Research 23:153-162.

Lieff, B. C., C. D. MacInnes, and R. K. Kistra. 1970. Food selection experiments with young geese. Journal of Wildlife Management 34:321-327.

Manny, B. A., W. C. Johnson, and R. G. Wetzel. 1994. Nutrient additions by waterfowl to lakes and reservoirs: predicting their effects on productivity and water quality. Hydrobiology 279:121-132.

Mathers, R. G., and W. I. Montgomery. 1997. Quality of food consumed by overwintering pale-bellied brent geese (Branta bernicla hrota) and wigeon (Anas penelope). Proceedings of the Royal Irish Academy 97B:81-89.

McKay, H. V., T. P. Milsom, C. J. Feare, D. C. Ennis, D. P. O'Connell, and D. J. Haskell. 2001. Selection of forage species and the creation of alternative feeding areas for dark-bellied brent geese (Branta bernicla bernicla) in southern UK coastal areas. Agriculture, Ecosystems \& Environment 84:99-113.

Messmer, T. A. 2009. Human-wildlife conflicts: emerging challenges and opportunities. Human-Wildlife Conflicts 3:10-17.

Miller, R. O. 1998. High-temperature oxidation: dry ashing. Pages 53-56 in Y. P. Kalra, editor. Handbook and reference methods for plant analysis. CRC Press, New York, New York, USA.

Mohr, M. M., W. A. Meyer, and C. Mansue. 2002. Incidence of Neotyphodium endophyte in seed lots of cultivars and selections of the 2001 National tall fescue test. 2002 Rutgers Turfgrass Proceedings, New Jersey Turfgrass Association, 10-12 December 2002, Atlantic City, USA.

Olsen, B., V. J. Munster, A. Wallensten, J. Waldenstrom, A. Osterhaus, and R. Fouchier. 2006. Global patterns of influenza A virus in wild birds. Science 312:384-388.
Owen, M. 1973. The management of grassland areas for wintering geese. Wildfowl 24:123-130.

Owen, M. 1975. Cutting and fertilizing grassland for winter goose management. Journal of Wildlife Management 39:163-167.

Owen, M. 1976. The selection of winter food by white-fronted geese. Journal of Applied Ecology 13:715-729.

Owen, M., M. Nugent, and N. Davies. 1977. Discrimination between grass species and nitrogen-fertilized vegetation by young barnacle geese. Wildfowl 28:21-26.

Pochop, P. A., J. L. Cummings, K. L. Wedemeyer, R. M. Engeman, and J. E. Davis. 1999. Vegetation preferences of captive Canada geese at Elmendorf Air Force Base, Alaska. Wildlife Society Bulletin 27:734740.

Pond, W. G., D. C. Church, and K. R. Pond. 1995. Basic animal nutrition and feeding. John Wiley and Sons, New York, New York, USA.

Prins, H. H. T., and R. C. Ydenberg. 1985. Vegetation growth and a seasonal habitat shift of the barnacle goose (Branta leucopsis). Oecologia 66:122-125.

Prop, J., and C. Deerenberg. 1991. Spring staging in Brent geese Branta benicula: feeding constraints and the impact of diet on the accumulation of body reserves. Oecologia 87:19-28.

Prop, J., W. D. Van Marken, J. H. Beekman, and J. F. Faber. 2005. Using food quality and retention time to predict digestion efficiency in geese. Wildlife Biology 11:21-29.

Schmidt, S. P., and T. G. Osborn. 1993. Effects of endophyte-infected tall fescue on animal performance. Agriculture, Ecosystems \& Environment 44:233-262.

Sedinger, J. S. 1997. Adaptations to and consequences of an herbivorous diet in grouse and waterfowl. Condor 99:314-326.

Sedinger, J. S., and D. G. Raveling. 1984. Dietary selectivity in relation to availability and quality of food for goslings of cackling geese. Auk 101:295-306.

Sedinger, J. S., R. G. White, F. E. Mann, F. A. Burris, and R. A. Kedrowski. 1989. Apparent metabolizability of alfalfa components by yearling Pacific black brant. Journal of Wildlife Management 53:726-734.

Smith, A. E., S. R. Craven, and P. D. Curtis. 1999. Managing Canada geese in urban environments: a technical guide. Cornell University Cooperative Extension Jack Berryman Institute Publication 16, Ithaca, New York, USA.

Ulrich, R. S. 1986. Human response to vegetation and landscapes. Landscape and Urban Planning 13:29-44.

Van Liere, D. W., N. J. M. Van Eekeren, and M. J. J. E. Loonen. 2009. Feeding preferences of greylag geese and the effect of activated charcoal. Journal of Wildlife Management 73:924-931.

Vicari, M., and D. R. Bazely. 1993. Do grasses fight back?-The case for antiherbivore defenses. Trends in Ecology and Evolution 8:137-141.

Washburn, B. E., S. C. Barras, and T. W. Seamans. 2007. Foraging preferences of captive Canada geese related to turfgrass mixtures. Human-Wildlife Conflicts 1:214-223.

Williams, G., and J. E. Forbes. 1980. The habitat and dietary preferences of dark-bellied brent geese and wigeon in relation to agricultural management. Wildfowl 31:151-157.

Ydenberg, R. C., and H. H. T. Prins. 1981. Spring grazing and the manipulation of food quality by barnacle geese. Journal of Applied Ecology 18:443-453.

York, D. L., J. L. Cummings, R. M. Engeman, and K. L. Wedemeyer. 2000. Hazing and movements of Canada geese near Elmendorf Air Force Base in Anchorage Alaska. International Biodeterioration \& Biodegredation 45:103-110.

Zar, J. H. 1996. Biostatistical analysis. Prentice-Hall, Upper Saddle River, New Jersey, USA.

Associate Editor: Bret Collier. 